\title{
IMPACT OF PRESSURE ON THE PARAMETERS OF PEA STRAW COMPACTION
}

\author{
Ryszard Kulig $^{\mathrm{a}^{*}}$, Grzegorz Łysiak ${ }^{\mathrm{a}}$, Zbigniew Krzysiak ${ }^{\mathrm{b}}$, Monika Wójcik ${ }^{\mathrm{a}}$, Renata Różyło \\ a Department of Food Engineering and Machines, University of Life Sciences in Lublin, Poland, \\ $\mathrm{b}$ Department of Mechanical Engineering and Automation, University of Life Sciences in Lublin, \\ Poland, ORCID 0000-0002-4950-7481
}

Ryszard Kulig ORCID 0000-0003-0994-8140; Grzegorz Łysiak ORCID 0000-0002-4942-3050; Monika Wójcika ORCID 0000-0002-2128-0334; Renata Różyło ORCID 0000-0002-3249-8929

* Corresponding author: e-mail: ryszard.kulig@up.lublin.pl

\begin{tabular}{|c|c|}
\hline ARTICLE INFO & ABSTRACT \\
\hline $\begin{array}{l}\text { Article history: } \\
\text { Received: August } 2019 \\
\text { Received in the revised form: } \\
\text { September } 2019 \\
\text { Accepted: September } 2019 \\
\end{array}$ & $\begin{array}{l}\text { This paper presents the results of pea straw compaction efficiency tests. } \\
\text { The compliance of the tested material to pressure agglomeration was } \\
\text { assessed depending on the compaction pressure used ( } 45-113 \mathrm{MPa} \text { ). } \\
\text { The compaction was carried out using a Zwick testing machine, type } \\
\text { Z020/TN2S, and a closed die pressing unit. It was found that, along }\end{array}$ \\
\hline $\begin{array}{l}\text { Keywords: } \\
\text { pea straw, } \\
\text { agglomeration, } \\
\text { energy consumption of pressure com- } \\
\text { paction, } \\
\text { quality of agglomerates }\end{array}$ & $\begin{array}{l}\text { with the pressure increase, the material density in the chamber increased } \\
\text { (from } 1.255 \text { to } 1.76 \mathrm{~g}^{-\mathrm{cm}^{-3}} \text { ), as well as the agglomerate's density (from } \\
0.739 \text { to } 1.05 \mathrm{~g} \cdot \mathrm{cm}^{-3} \text { ) and the product's mechanical resistance (from } 0.31 \\
\text { to } 0.69 \mathrm{MPa} \text { ). Increasing the compaction pressure in the analyzed range } \\
\text { increased the unit value of compaction work, from } 17.16 \text { to } 34.27 \mathrm{~J} \cdot \mathrm{g}^{-1} \text {. }\end{array}$ \\
\hline
\end{tabular}

\section{Introduction}

The constantly growing role of renewable energy in the energy balance increases the economic use of waste from agri-food production (Danish and Wang, 2019; Mao et al., 2018, Zdanowska et al. 2019). In this context, straw is of great importance (Kwaśniewski and Kuboń, 2016; Lisowski et al., 2018). As a raw material for the production of solid biofuels, straw of virtually all types of arable crops, including legumes, can be used. This is important because in the case of plants such as peas, the straw is usually left unused and plowed down.

Straw, in combination with other commonly used energy carriers, is a fuel quite cumbersome to use. Unlike conventional sources, it is a heterogeneous material with a lower energy value, especially per unit of volume (Adamczyk et al., 2005, 2006). This state of affairs requires changing its original form into agglomerates obtained in the process of pressure compaction (Hejft, 2002). In consequence, it allows to significantly reduce the costs associated with the distribution and use of plant biomass for energy purposes.

Many studies demonstrate that in the production process of molded solid biofuels, the value of the applied compaction pressure (i.e. unit piston pressure) (Li and Liu, 2000; Mani et al., 2006) and the moisture content of the raw material (Relova et al., 2009; Kulig and Skonecki, 2011) is of great importance. The value of these parameters impacts both the 
course of the process and the quality of the finished product (Whittaker and Shield, 2017). Application of too low a pressure results in agglomerates with insufficient mechanical durability. However, an uncontrolled increase of the pressure can lead to an unnecessary increase in energy consumption and wear of the working elements of production equipment.

Earlier studies of the author presented the results of research on the impact of the above parameter on the efficiency of pressure compaction of biomass of various origins (Kulig et al. 2013, 2014). This work is a continuation of research in this area. Therefore, the purpose of the work was to determine the impact of a piston pressure unit on the parameters of the compaction process of crushed pea straw.

\section{Material and methods}

The research material was pea straw, collected during the 2019 harvest. The raw material was cut into $20 \mathrm{~mm}$ chaff. Then the thus prepared material was crushed using a beater shredder (type ML-500) equipped with a sieve with a hole diameter of $\phi 4 \mathrm{~mm}$. The compaction was carried out for raw material with 10 and $20 \%$ humidity. The bulk density of the raw material - determined in accordance with PN-ISO 7971-2: 1998 - was respectively: 0.151 $\mathrm{g} \cdot \mathrm{cm}^{-3}$ for $10 \%$ humidity, and $0.162 \mathrm{~g} \cdot \mathrm{cm}^{-3}$ for $20 \%$ humidity.

A ZWICK strength testing machine, type Z020/TN25, and a closed die pressing unit were used in compaction tests. The research was carried out in accordance with the methodology presented by Laskowski and Skonecki (2001). A matrix with a chamber diameter $d=15 \mathrm{~mm}$ was used, in which a $2 \mathrm{~g}$ mass was compacted. The temperature of the cylinder (and of compacted material) was $20^{\circ} \mathrm{C}$, and piston speed was $10 \mathrm{~mm} \cdot \mathrm{min}^{-1}$. The compaction was carried out for five values of the maximum compaction force, i.e. 8, 11, 14, 17 and $20 \mathrm{kN}$, which corresponded to the following compaction pressure values: 45, 62, 79, 96 and $113 \mathrm{MPa}$. Each process was carried out in a triplicate.

The effect of the measurement was the compaction characteristics curve, demonstrating the dependence of compaction force on piston shifts (Fig. 1). The maximum material density in the chamber was determined based on the curve $\rho_{c}$ and total compaction work $L_{c}$. Material susceptibility to compaction $k_{c}\left(k_{c}=L_{c}{ }^{\prime} \cdot\left(\rho_{c}-\rho_{n}\right)^{-1}\right.$ was calculated, where: $L_{c}{ }^{\prime}=L_{c} \cdot m^{-1}-$ unit value of compaction work, $m$ - the mass of the material sample, $\rho_{n}$ - bulk density of the raw material. After 48 hours of storage, the agglomerate density $\rho_{a}$ was determined for the obtained briquette. The agglomerate compaction degree $S_{z a}$ was also determined, based on the formula: $S_{z a}=\rho_{a} \cdot \rho_{n}{ }^{-1}$. 


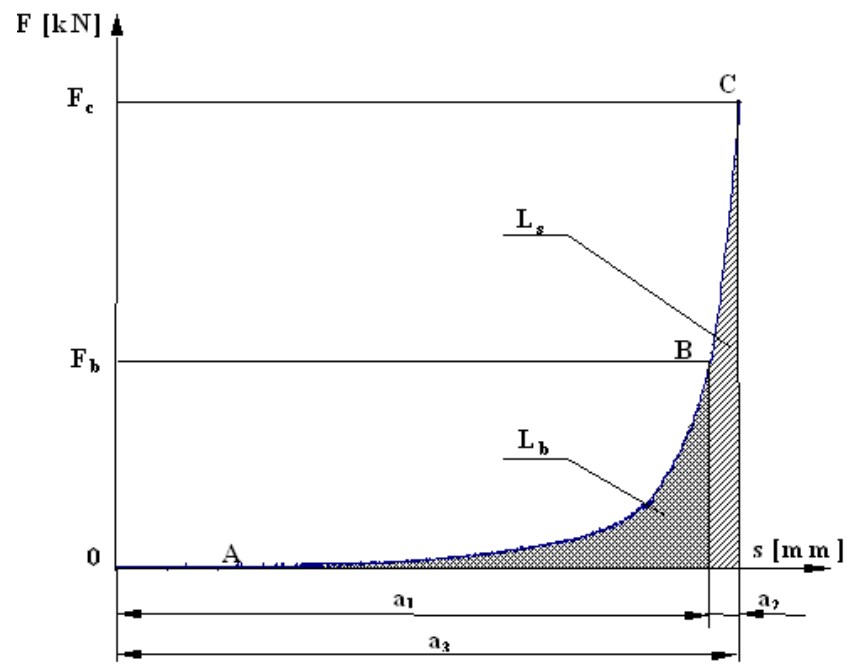

Figure 1. Compaction characteristics: $a_{1-}$ proper compaction, $a_{2}-$ compression, $a_{3}-e x-$ trusion (Laskowski and Skonecki, 2001)

Next, the agglomerate quality was determined, in terms of mechanical durability. Mechanical resistance of the agglomerate was determined by the so-called Brazilian test, using the ZWICK Z020/TN2S testing machine. Mechanical resistance $\sigma_{n}(\mathrm{MPa})$ was calculated from the formula (Ruiz et al., 2000):

$$
\sigma_{n}=\frac{2 F_{n}}{\pi d l} \quad(\mathrm{MPa})
$$

where:

d - agglomerate diameter, $(\mathrm{mm})$

$l \quad-$ agglomerate length, $(\mathrm{mm})$

$F_{n} \quad-$ agglomerate destructive force, $(\mathrm{N})$

\section{Results and discussion}

Regression equations that describe the dependence of the examined process parameters on the compaction pressure are presented in Tab. 1. Figures 2-5 show that the impact of pressure on the course of the compaction process and the properties of the obtained agglomerate (for each raw material moisture content tested) can be described by linear and logarithmic models $\left(\alpha_{a}=0.01\right)$.

The relationships shown in Fig. 2 indicate that with the increase of the compaction pressure, the maximum raw material density in the chamber $\rho_{c}$ increased, as did the density of the agglomerate $\rho_{a}$. The range of density variability $\rho_{c}$ for the examined raw materials ranged from 1.255 to $1.76 \mathrm{~g} \cdot \mathrm{cm}^{-3}$. Higher values of this parameter were obtained for the raw material with $20 \%$ humidity. It should be assumed that the wetter raw material must have increased its plasticity, which led to an increase in particle packing. Similar comments were also made 
by Mani et al. (2006). In contrast, the density of the agglomerate after storage $\rho_{a}$ was higher for the raw material with $10 \%$ humidity (the range varied from 0.949 to $1.05 \mathrm{~g} \cdot \mathrm{cm}^{-3}$ ). For the raw material with $20 \%$ humidity, the values of this parameter ranged from 0.739 to $0.96 \mathrm{~g} \cdot \mathrm{cm}^{-3}$. A significant increase in density $\rho_{a}$ occurred in the pressure range of 45-96 MPa. However, a further increase in pressure practically did not contribute to increasing the density of the obtained agglomerate. With reference to pressures 96 and $113 \mathrm{MPa}$, the obtained differences in parameter values $\rho_{a}$, were not statistically significant $(\mathrm{p}>0.01)$.

Table 1.

Regression equations describing the dependence of density $\rho_{c}, \rho_{a}$, the density of the agglomerate $S_{z a}$, mechanical resistance $\delta_{m}$. work $L_{. c}{ }^{\prime}$ and the coefficient $k_{c}$ on the compaction pressure $P$ and the value of the determination coefficient $R^{2}$

\begin{tabular}{lclc}
\hline Process parameter & Raw material moisture & Regression equation & $\mathrm{R}^{2}$ \\
\hline Density of the material & $10 \%$ & $\rho_{c}=0.1 P+1.725$ & 0.918 \\
in the chamber, $\left(\rho_{c}\right)$ & $20 \%$ & $\rho_{c}=0.09 P+1.319$ & 0.989 \\
\hline Density of the agglom- & $10 \%$ & $\rho_{a}=0.125 \ln P+0.468$ & 0.918 \\
erate after 48 hours, $\left(\rho_{a}\right)$ & $20 \%$ & $\rho_{a}=0.253 \ln P-0.234$ & 0.972 \\
\hline Degree of agglomerate & $10 \%$ & $S_{z a}=0.835 \ln P+3.12$ & 0.929 \\
compaction, $\left(S_{z a}\right)$ & $20 \%$ & $S_{z a}=1.581 \ln P+1.465$ & 0.972 \\
\hline Mechanical resistance & $10 \%$ & $\delta_{m}=0.173 \ln P+0.168$ & 0.971 \\
of the agglomerate, $\left(\delta_{m}\right)$ & $20 \%$ & $\delta_{m}=0.309 \ln P+0.903$ & 0.984 \\
\hline Compaction work, $\left(L_{c}{ }^{\prime}\right)$ & $10 \%$ & $L_{c}{ }^{\prime}=0.165 P+13.98$ & 0.980 \\
\hline Coefficient of material & $20 \%$ & $L_{c}=0.194 P+8.66$ & 0.971 \\
compaction compliance, & $10 \%$ & $k_{c}=0.034 P+17.613$ & 0.959 \\
$\left(k_{c}\right)$ & $20 \%$ & $k_{c}=0.075 P+10.56$ & 0.972 \\
\hline
\end{tabular}

Changes in agglomerate density $S_{z a}$, dependent on the compaction pressure, were illustrated in Fig. 3. The values obtained characterize the scope of agglomerate density change after its removal from the die and expansion within 48 hours of storage, as compared to the initial density of the material. As the unit pressure of the piston increases, the degree of agglomerate density $S_{z a}$ increased, ranging from 4.618 to 6.993 . Higher values of $S_{z a}$ obtained for the raw material with $10 \%$ moisture demonstrate that its agglomerate freely expanded to a lesser degree than the product obtained from the raw material with $20 \%$ moisture. As a result, it achieved higher density values. In this case, the density of the agglomerate after storage was greater than the initial density of the raw material by approx. 6 to 7 times. As in the case of density changes $\rho_{a}$, the largest increase in parameter value $S_{z a}$ for both tested material moistures occurred in the pressure range of 45-96 MPa. 
Impact of pressure on...

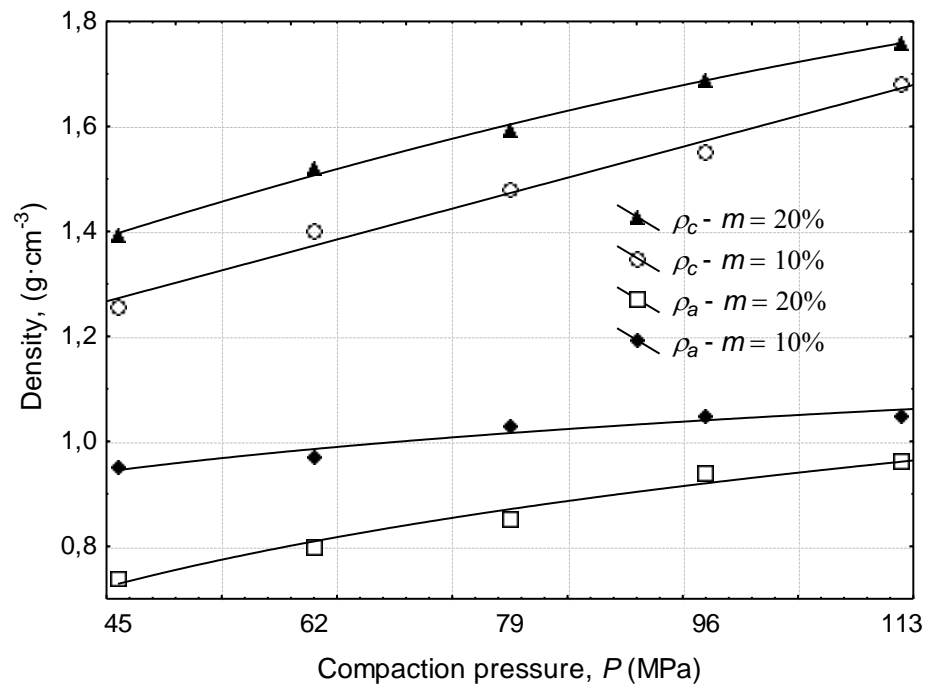

Figure 2. The relationship between the density of the material in the compaction chamber $\left(\rho_{c}\right)$ and the density of the agglomerate $\left(\rho_{a}\right)$, and the compaction pressure $(P)$ for various raw material moistures $(m)$

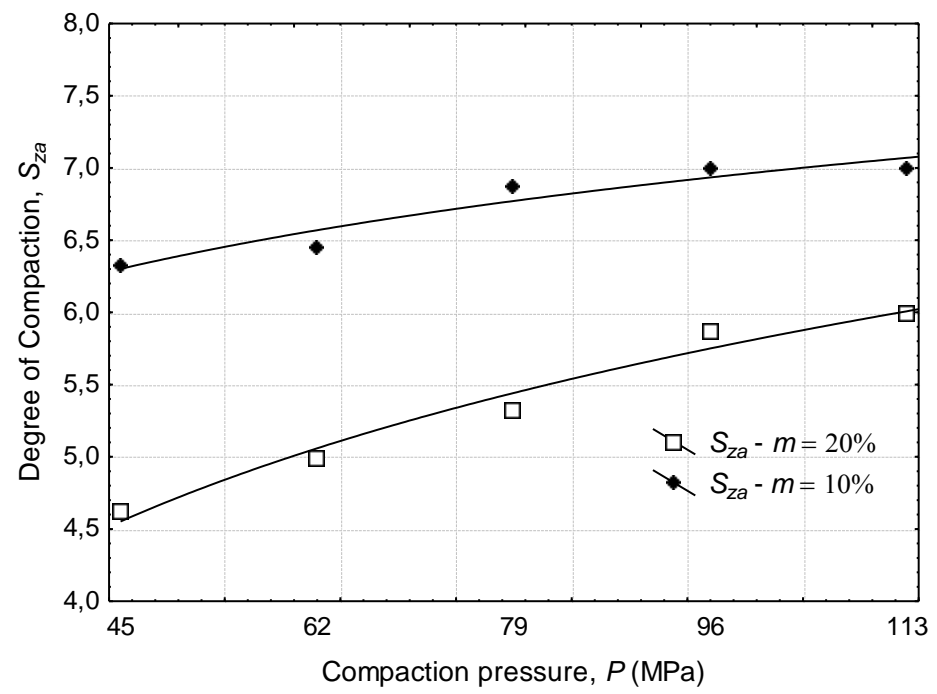

Figure 3. The relationship between the degree of agglomerate density $\left(S_{z a}\right)$ and the compaction pressure $(P)$ for different raw material moistures $(m)$

The higher density of the agglomerate, obtained as a result of increasing the compaction pressure, had a positive effect on the mechanical strength of the obtained products. The results of the mechanical strength tests showed that as the compaction pressure increased, so 
did the agglomerate's mechanical strength, irrespective of its humidity (Fig. 4). The highest value of the analyzed parameter $(0.69 \mathrm{MPa})$ characterized the $10 \%$ humidity agglomerate, obtained when using $113 \mathrm{MPa}$ pressure. By contrast, the lowest value of $\sigma_{n}(0.31 \mathrm{MPa})$ was obtained for the $20 \%$ humidity raw material product, compacted at $45 \mathrm{MPa}$.

Compared to the tests carried out on other plant raw materials (Mani et al., 2006; Relova et al., 2009; Skonecki and Kulig, 2011), the performed pea straw agglomeration tests confirmed the tendencies of the agglomerate to change its density and mechanical strength, depending on the pressure applied, and moisture content.

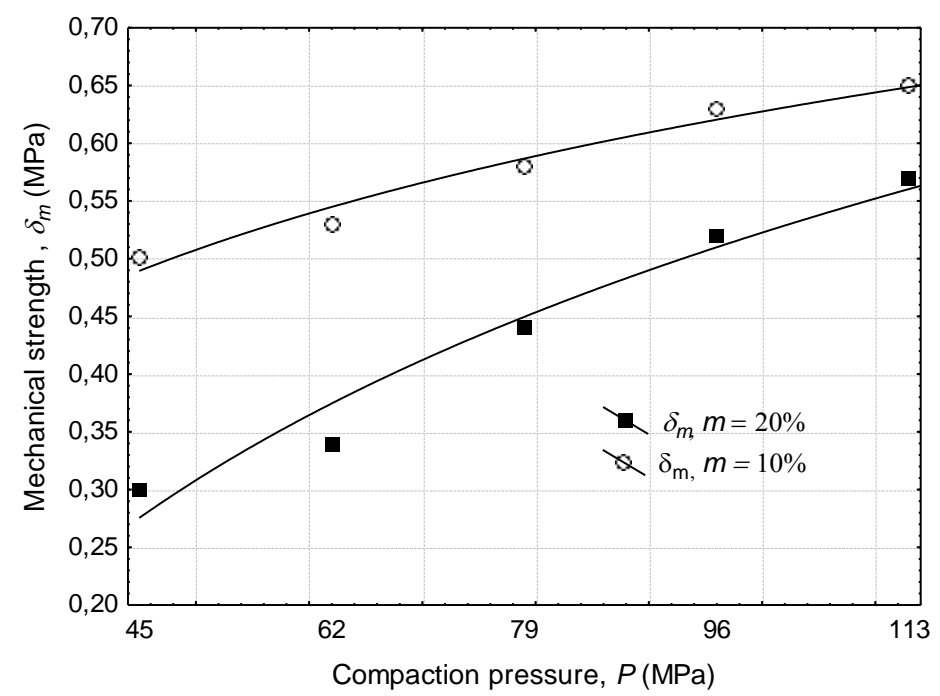

Figure 4. Relationship between mechanical resistance $\left(\delta_{m}\right)$ of the agglomerate and the compaction pressure $(P)$ for different raw material moistures $(m)$

The test results presented in Fig. 5 indicate that the increase in compaction pressure caused an increase of the unit value of compaction work for each tested raw material. Thus, obtaining agglomerates with the highest density and mechanical resistance was associated with higher energy expenditures each time. The value of work $L_{c}{ }^{\prime}$ ranged from $17.16 \mathrm{~J} \cdot \mathrm{g}^{-1}$ for the pressure of $45 \mathrm{MPa}$ (raw material with $20 \%$ humidity) to $34.27 \mathrm{~J} \cdot \mathrm{g}^{-1}$ for a pressure of $113 \mathrm{MPa}$ (raw material with $10 \%$ humidity). Compaction of the raw material with $20 \%$ humidity was characterized by lower energy consumption in the entire tested range of pressure variability. Also in this case, increasing the humidity $(\mathrm{m})$ probably caused the compacted material to become more plastic and its compaction compliance to increase, as evidenced by the lower value of the compaction compliance coefficient $k_{c}$ (Fig. 5). The minimum value of $k_{c}$ for $m=20 \%(P=45 \mathrm{MPa})$ was $13.68 \mathrm{~J} \cdot \mathrm{cm}^{3} \cdot \mathrm{g}^{-2}$, and the maximum was $18.63 \mathrm{~J} \cdot \mathrm{cm}^{3} \cdot \mathrm{g}^{-2}$ $(P=113 \mathrm{MPa})$. However, for humidity $m=10 \%$, coefficient $k_{c}$ increased from $17.2 \mathrm{~J} \cdot \mathrm{cm}^{3} \cdot \mathrm{g}^{-2}$ to $21.45 \mathrm{~J} \cdot \mathrm{cm}^{3} \cdot \mathrm{g}^{-2}$ along with the increasing compaction pressure, from 45 to $113 \mathrm{MPa}$. The obtained results for coefficient $k_{c}$ confirm its tendency to change along with the increasing agglomeration pressure, as for the compaction of other raw materials (Kulig et al. 2013, 2014). 


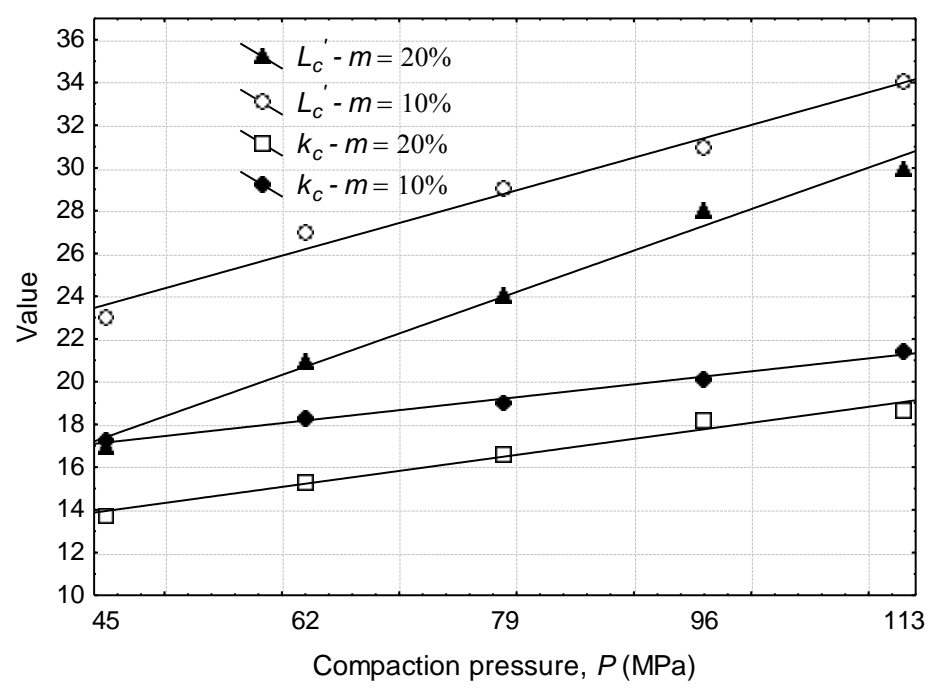

Figure 5. Relationship between a unit value of compaction work $\left(L_{c} \cdot\right)$ and the material compaction compliance coefficient $\left(k_{c}\right)$ and compaction pressure $(P)$ for various raw material moistures (m)

\section{Conclusions}

Based on the results of the research, the following conclusions can be made:

1. The increase in unit piston pressure from 45 to $113 \mathrm{MPa}$ increases the maximum density of the raw material in the chamber $\left(\rho_{c}\right)$ by $26.5 \%$ on average.

2. It has been demonstrated that increasing the compaction pressure in the range of 45-96 MPa causes an increase in the agglomerate's density $\rho_{a}$ (by $29.7 \%$ on average), and in the agglomerate's density values $S_{z a}$ (by $33 \%$ on average). However, further increase in the value of the unit piston pressure brings no statistically significant changes in the values of the parameters considered.

3. Mechanical strength $\sigma_{n}$ of the obtained agglomerates increased along with the increase in compaction pressure, by $78.8 \%$ on average. Higher values $\sigma_{n}$ (on average by $32 \%$ ) has been shown for agglomerate obtained from raw material with $10 \%$ moisture content.

4. It was found that increasing the compaction pressure in the examined ranges caused an increase in the unit value of compaction work $L_{c}{ }^{\prime}$ and the material efficient on compaction $k_{c}$. In the first case, the average increase in value was $66.3 \%$, and in the second case, $31.42 \%$. 


\section{References}

Adamczyk, F., Frąckowiak, P., Mielec, K., Kośmicki, Z. (2005). Problematyka badawcza w procesie zagęszczania słomy przeznaczonej na opał. Journal of Research and Application in Agricultural Engineering, 50(4), 5-8.

Adamczyk, F., Frąckowiak, P., Mielec, K., Kośmicki, Z., Zielnica, M. (2006). Badania eksperymentalne procesu zagęszczania słomy metodą zwijania. Journal of Research and Application in Agricultural Engineering, 51(3), 5-10.

Danish, Z., Wang, Z. (2019). Does biomass energy consumption help to control environmental pollution? Evidence from BRICS countries. Science of the Total Environment, 670, 1075-1083.

Hejft, R. (2002). Ciśnieniowa aglomeracja materiałów roślinnych. Politechnika Białostocka. Wyd. $i$ Zaktad Poligrafii Instytutu Technologii Eksploatacji w Radomiu.

Kulig, R., Skonecki, S. (2011). Wpływ wilgotności na parametry procesu zagęszczania wybranych roślin energetycznych. Acta Agrophysica, 17(2), 335-344.

Kulig, R., Skonecki ,S., Łysiak, G., Laskowski, J., Rudy, S., Krzykowski, A., Nadulski, R. (2013). The effect of pressure on the compaction parameters of oakwood sawdust enhanced with a binder. Teka Commission of Motorization and Energetics in Agriculture, 13(1), 83-88.

Kulig, R., Skonecki, S., Gawłowski, S., Zdybel, A., Łysiak, G. (2013). Oddziaływanie ciśnienia na efektywność zagęszczania trocin wybranego drewna miękkiego. Acta Scientiarum Polonorum. Technica Agraria, 12(1-2), 31-40.

Kulig, R., Łysiak, G., Skonecki, S., Kobus ,Z., Rydzak, L., Guz, T. (2014). Określenie zależności między ciśnieniem a parametrami zagęszczania wybranych roślin energetycznych. Motrol - Motoryzacja i Energetyka Rolnictwa, 16(1), 55-58.

Kwaśniewski, D., Kuboń, M. (2016). Efektywność ekonomiczna produkcji peletów ze słomy zbóż. Agricultural Engineering, 20(4), 147-155.

Laskowski, J., Skonecki, S. (2001). Badania procesów aglomerowania surowców paszowych - aspekt metodyczny. Inżynieria Rolnicza, 2(22), 187-193.

Li, Y., Liu, H. (2000). High pressure densification of wood residues to form an upgraded fuel. Biomass and Bioenergy, 19(3), 177-186.

Lisowski, A., Matkowski, P., Dąbrowska, M., Piątek, M., Świętochowski, A., Klonowski, J., Mieszkalski, L., Reshetiuk, V. (2018). Particle Size Distribution and Physicochemical Properties of Pellets Made of Straw, Hay, and Their Blends. Waste and Biomass Valorization. https://doi.org/ 10.1007/s12649-018-0458-8.

Mani, S., Tabil, L.G., Sokhansanj, S. (2006). Effects of compressive force, particle size and moisture content on mechanical properties of biomass pellets from grasses. Biomass and Bioenergy, 30(7), 648-654.

Mao, G., Huang, N., Chen, L., Wang, H. (2018). Research on biomass energy and environment from the past to the future: A bibliometric analysis. Science of the Total Environment, 635, 1081-1090.

Relova, I., Vignote, S., León, M. A., Ambrosio, Y. (2009). Optimisation of the manufacturing variables of sawdust pellets from the bark of Pinus caribaea Morelet: Particle size, moisture and pressure. Biomass and Bioenergy, 33, 1351-1357.

Ruiz, G., Ortiz, M., Pandolfi, A. (2000). Three-dimensional finite-element simulation of the dynamic Brazilian tests on concrete cylinders. International Journal for Numerical Methods in Engineering. 48, 963-994.

Skonecki, S., Kulig, R. (2011). Wpływ wilgotności biomasy roślinnej i nacisku tłoka na parametry brykietowania i wytrzymałość aglomeratu. Autobusy, Technika, Eksploatacja, Systemy transportowe, 10, 375-386.

Whittaker, C., Shield, I. (2017). Factors affecting wood, energy grass and straw pellet durability A review. Renewable and Sustainable Energy Reviews, 71, 1-11. 
Impact of pressure on...

Zdanowska, P., Florczak, I., Słoma, J., Tucki, K., Orynycz, O., Wasiak, A.L., Świć, A. (2019). An Evaluation of the Quality and Microstructure of Biodegradable Composites as Contribution towards Better Management of Food Industry Wastes. Sustainability, 11(5), 1504

\section{WPLYW CIŚNIENIA NA PARAMETRY PROCESU ZAGESZCZANIA SLOMY GROCHOWEJ}

Streszczenie. Przedstawiono wyniki badań efektywności zagęszczania słomy grochowej. Oceniono podatność badanego materiału na proces aglomerowania ciśnieniowego w zależności od stosowanego ciśnienia zagęszczania (od 45 do $113 \mathrm{MPa}$ ). Zagęszczanie przeprowadzano przy wykorzystaniu maszyny wytrzymałościowej Zwick typ Z020/TN2S i zespołu prasującego z matrycą zamkniętą. Stwierdzono, że wraz ze wzrostem ciśnienia rosła gęstość materiału w komorze (w zakresie od 1,255 do $1,76 \mathrm{~g} \cdot \mathrm{cm}^{-3}$ ) i gęstość aglomeratu (w zakresie od $0,739 \mathrm{do} 1,05 \mathrm{~g} \cdot \mathrm{cm}^{-3}$ ) oraz zwiększała się odporność mechaniczna produktu (w przedziale od 0,31 do 0,69 MPa). Zwiększanie ciśnienia zagęszczania $\mathrm{w}$ analizowanym przedziale powodowało wzrost wartości jednostkowej pracy zagęszczania $\mathrm{w}$ zakresie od 17,16 do $34,27 \mathrm{~J} \cdot \mathrm{g}^{-1}$.

Słowa kluczowe: słoma grochowa, aglomerowanie, energochłonność zagęszczania ciśnieniowego, jakość aglomeratów 